\title{
KONSEP DIRI DAN KETIDAKBERDAYAAN BERHUBUNGAN DENGAN RISIKO BUNUH DIRI PADA REMAJA YANG MENGALAMI BULLYING
}

\author{
Udi Wahyudi*, Bram Burnamajaya \\ Program Studi Keperawatan Bogor, Politeknik Kesehatan Bandung, Jl. DR. Sumeru No.116, Menteng, Bogor \\ Barat., Kota Bogor, Jawa Barat, Indonesia 16111 \\ *udi120872@gmail.com
}

\begin{abstract}
ABSTRAK
Bullying merupakan perilaku negatif yang dilakukan secara berulang-ulang oleh seseorang atau sekelompok orang yang bersifat menyerang karena adanya ketidakseimbangan kekuatan antara pihak yang terlibat.Tindakan bullying dapat berdampak buruk bagi korban maupun pelakunya di masa depannya. Dampak tersebut meliputi kesepian, pencapaian akademik yang buruk, kesulitan penyesuaian (adaptasi), meningkatnya risiko penggunaan zat, keterlibatan dalam tindakan kriminal dan kerentanan gangguan mental emosional seperti cemas, insomnia, penyalahgunaan zat, depresi, mempunyai self-esteem rendah, kesulitan interpersonal, gangguan konsep diri, dan depresi (ketidakberdayaan). Tujuan penelitian ini adalah untuk mengetahui hubungan antara konsep diri dan ketidakberdayaan dengan risiko bunuh diri pada remaja yang mengalami bullying di SMA Negeri 7 Kota Bogor. Penelitian ini merupakan penelitian kuantitatif dengan menggunakan metode crosssectional study dengan bentuk pendekatan rancangan correlation study. Sampel dalam penelitian ini berjumlah 183 orang didapat dari teknik randomsampling. Hasil penelitian menunjukkan bahwa berdasarkan hasil uji hubungan dengan menggunakan Chi-Square antara konsep diri dengan ketidakberdayaan didapatkan nilai $\rho(0,000)$ lebih kecil daripada nilai $a(0,05)$, sedangkan uji hubungan antara konsep diri dengan risiko bunuh diri didapatkan nilai $\rho(0,013)$ lebih kecil daripada nilai $\alpha(0,05)$. Dengan demikian bahwa ada hubungan antara konsep diri dan ketidakberdayaan dengan risiko bunuh diri pada remaja yang mengalami bullying di SMA Negeri 7 Kota Bogor.
\end{abstract}

Kata kunci: bullying, konsep diri, ketidakberdayaan, risisko bunuh diri

\section{SELF-CONCEPT AND INEQUALITY CONNECTED WITH RISK OF SELF- SUFFICIENT IN ADOLESCENTS WHO HAVE BULLYING}

\begin{abstract}
Bullying is a negative behavior that is carried out repeatedly by a person or group of people who are attacking because of an imbalance of power between the parties involved. Bullying actions can have a negative impact on victims and perpetrators in the future. These impacts include loneliness, poor academic achievement, adaptation difficulties, increased risk of substance use, involvement in criminal acts and susceptibility to mental emotional disorders such as anxiety, insomnia, substance abuse, depression, low self-esteem, interpersonal difficulties, disturbances self concept, and depression (helplessness). The purpose of this study was to determine the relationship between selfconcept and powerlessness with the risk of suicide in adolescents who experienced bullying in SMA Negeri 7 Kota Bogor. This research is a quantitative study using a cross-sectional study method with a correlation study design approach. The sample in this study amounted to 183 people obtained from random sampling techniques. The results showed that based on the results of the relationship test using Chi-Square between self-concept and powerlessness, the value of $\rho(0,000)$ was smaller than the value of a (0.05), while the test of the relationship between self-concept and risk of suicide obtained a value of $\rho(0.013)$ is smaller than the value of $\alpha(0.05)$. Thus that there is a relationship between selfconcept and powerlessness with the risk of suicide in adolescents who experience bullying in SMA Negeri 7 Kota Bogor.
\end{abstract}

Keywords: bullying, self-concept, helplessness, suicide risk 


\section{PENDAHULUAN}

Bullying (perundungan) merupakan perilaku negatif yang dilakukan secara berulang-ulang oleh seseorang atau sekelompok orang yang bersifat menyerang karena adanya ketidakseimbangan kekuatan antara pihak yang terlibat. Menurut Murphy (2009) bullying adalah saat seseorang mengalami kekerasan, dipermalukan, memperoleh ancaman oleh orang lain melalui media internet maupun melalui berbagai media teknologi interaktif, seperti telepon seluler, termasuk diantaranya pesan teks singkat (SMS) atau email ancaman, membuat webpage berisikan informasi baik yang benar maupun tidak benar yang mempermalukan seseorang atau aktivitas membagikan/menceritakan rahasia pribadi seseorang dalam publik di internet.

Tindakan bullying dapat berdampak buruk bagi korban maupun pelakunya di masa depannya. Dampak buruk akibat perilaku bullying terhadap korban yang paling sering adalah gangguan konsep diri. Konsep diri merupakan suatu cara untuk memprediksi tingkah laku individu. Konsep diri terbentuk dan berkembang dipengaruhi oleh pengalaman atau kontrak eksternal dengan lingkungannya dan juga pengalaman internal tentang dirinya. Pengalaman internal ini akan mempengaruhi respon terhadap pengalaman eksternalnya. Konsep diri merupakan faktor yang sangat menentukan dalam perilaku seseorang. Konsep diri terbagi menjadi dua, yaitu positif dan negatif (Fatimatul, 2009).

Pada seorang remaja yang mengalami perilaku bullying akan mempunyai konsep diri yang negatif, yaitu remaja akan memandang dirinya lemah, tidak berdaya, tidak kompeten, tidak menarik, cenderung bersikap pesimistik terhadap kesempatan yang ada. Dengan konsep diri negatif remaja akan mudah menyerah, selalu menyalahkan dirinya maupun orang lain jika mengalami kegagalan.

Hasil studi yang dilakukan National Youth Violence Prevention Resource Center Sanders (Ansty, 2009) menunjukkan bahwa bullying dapat membuat remaja cemas dan ketakutan, mempengaruhi konsentrasi belajar di sekolah dan menuntun mereka untuk menghindari sekolah, bila bullying berlanjut dalam jangka waktu yang lama, dapat mempengaruhi self esteem remaja, meningkatkan isolasi sosial, memunculkan perilaku menarik diri, menjadikan remaja rentan terhadap stress dan depresi serta rasa tidak aman. Dalam kasus yang lebih ekstrim, bullying dapat mengakibatkan remaja berbuat nekat, bahkan bisa membunuh atau melakukan bunuh diri (commited suicide).

Menurut Rievers (2010) bahwa korban bullying rentan memiliki ide atau percobaan bunuh diri serta melakukan pembalasan. Hasil survey yang dilakukan di Amerika Serikat bahwa ada 10\% atau 1 dari 13 siswa SMU korban bullying melakukan percobaan bunuh diri yang disebabkan oleh depresi atau ketidakberdayaan.

Rutter dan Behrendt juga menjelaskan bahwa ada empat faktor psikososial yang penting sebagai faktor risiko bunuh diri pada remaja yaitu ketidakberdayaan, permusuhan, konsep diri yang negatif, dan terisolasi. Selain itu, penelitian Kwok dan Shek (2010) memperoleh hasil bahwa ide-ide bunuh diri pada remaja memiliki hubungan dengan ketidak berdayaan, dan kuatnya hubungan antara ide-ide bunuh diri dengan ketidakberdayaan tersebut terjadi dalam kondisi lemahnya komunikasi antara orang tua dengan remaja. Berdasarkan pemaparan tersebut, dapat dilihat bahwa salah satu faktor yang kuat yang dikenali sebagai faktor yang menyebabkan bunuh diri adalah ketidakberdayaan.

Bunuh diri adalah suatu tindakan mengakhiri kehidupan dengan sengaja. Sedangkan menurut Stuart (2009) bunuh diri adalah kematian dengan melukai diri sendiri, menggunakan racun atau mati lemas yang dilakukan sendiri. Perilaku bunuh diri dibagi dalam kategori ide bunuh diri, ancaman bunuh diri, upaya bunuh diri dan bunuh diri. Ide bunuh diri adalah pikiran yang membebani seseorang untuk mengakhiri hidupnya baik yang disampaikan oleh diri sendiri maupun melalui orang lain. Ancaman bunuh diri adalah tanda secara langsung ataupun tidak langsung, verbal atau nonverbal dari individu untuk mengakhiri hidupnya. Percobaan bunuh diri adalah tindakan seseorang secara langsung, ditujukan pada diri sendiri yang dapat menyebabkan kematian jika tidak dihentikan.

Indonesia menduduki urutan ke dua dunia dengan kasus bullyingnya. Berdasarkan hasil survey oleh Putik Psychology Center Indonesia bahwa ada 3,5 juta siswa di Indonesia yang menjadi korban bully setiap tahunnya. KPAI juga melaporkan berdasarkan hasil pengaduan, bahwa kasus bullying menduduki peringkat teratas pengaduan masyarakat ke Komisi Perlindungan Anak Indonesia (KPAI) dari sektor pendidikan. KPAI mencatat 369 pengaduan 
terkait bullying dari bulan Januari 2011 sampai Agustus 2014. Sedangkan berdasarkan hasil riset lembaga swadaya masyarakat (LSM) Plan International dan International Center for Research on Women (ICRW), hasilnya terdapat $84 \%$ anak di Indonesia yang mengalami bullying atau setara dengan tujuh dari 10 anak di Indonesia terkena tindak kekerasan di sekolah (Hariandja, 2015). Sedangakan berdasarkan hasil kajian Konsorsium Nasional Pengembangan Sekolah Karakter pada tahun 2014, hampir setiap sekolah di Indonesia terjadi bullying dalam bentuk verbal maupun psikologis/mental. Di Bogor angka kejadian bullying sekitar $40 \%$ dari jumlah siswa.

Hasil survey di kota Bogor yang dilakukan oleh Mahasiswa Departemen Ilmu Keluarga dan Konsumen (IKK) (2014) terhadap siswa SMK di kota Bogor menunjukkan bahwa persentase terbesar bentuk bullying yang dilakukan oleh remaja berjenis kelamin laki-laki $(36,4 \%)$ adalah bullying fisik. Sedangkan, remaja berjenis kelamin perempuan cenderung melakukan bullying dalam bentuk verbal $(44,2 \%)$ (Hastuti, 2015).

Berdasarkan hasil studi pendahuluan didapatkan informasi bahwa kasus bullying yang dilakukan oleh kakak kelas terhadap adik kelas nya pun terjadi di SMAN 7 Kota Bogor (tempat penelitian), yaitu seorang siswa kelas X di bully oleh 20 orang seniornya dengan cara dipaksa untuk minum-minuman beralkohol dan diajari cara tawuran dan dipukuli serta ditendang oleh kakak kelasnya, yaitu kelas XII.

\section{METODE}

Penelitian ini merupakan penelitian kuantitatif dengan menggunakan metode cross-sectional study dengan bentuk pendekatan rancangan correlation study, yaitu suatu rancangan yang digunakan untuk mencari hubungan antara konsep diri dan ketidakberdayaan dengan risiko bunuh diri pada remaja yang mengalami bullying.Populasi dalam penelitian ini adalah seluruh siswa SMA Negeri 7 Kota Bogor Kelas $\mathrm{X}$ dengan jumlah sampel sebanyak 183 siswa. Pengambilan sampel menggunakan teknik randomsampling, yaitu pengambilan sampel yang dilakukan secara acak. Adapun kriteria sampel adalah siswa yang mengalami bullying dan bersedia sebagai responden penelitian. Kegiatan penelitian mulai dari perijinan sampai dengan pengambilan data dilakukan dari bulan April sampai Agustus 2018.

Pengambilan data dilakukan dengan menggunakan kuesioner yang terdiri dari format Measuring Bullying Victimization, untuk mengukur bullying, format Tennessee Self Concept Scale (TSCS) untuk mengukur konsep diri remaja, Format Learned Helplessnes (LHS) untuk mengukur ketidakberdayaan dan instrumen Scale of Suicidal Ideation untuk mengukur risiko bunuh diri. Sebelum dilakukan random sampling untuk menentukan responden, peneliti melakukan screening terhadap siswa yang mengalami bullying dari sejumlah populasi yang ada, yaitu 308 siswa. Dari hasil screening didapatkan 183 siswa yang mengalami bullying yang kemudian dijadikan sebagai sampel penelitian. Setelah menentukan responden, maka peneliti menjelaskan tujuan dari kegiatan dan meminta persetujuan keikutsertaan dalam kegiatan penelitian serta menjelaskan cara pengisian kuesioner. Penelitian ini telah lolos Ethical Clearence dengan nomor:41/KEPK/PE/IX/2018

\section{HASIL}

Adapun karakteristik remaja sebagai berikut.

Tabel 1

Karakteristik Remaja Yang Mengalami Bullying $(\mathrm{n}=183)$

\begin{tabular}{cccc}
\hline Karakteristik Responden & Katagori & $\mathrm{f}$ & $\%$ \\
\hline \multirow{2}{*}{ Usia } & $12-15$ tahun & 79 & 43,17 \\
& $16-18$ tahun & 106 & 57,92 \\
\hline \multirow{2}{*}{ Jenis Kelamin } & Laki-laki & 97 & 53,55 \\
\cline { 2 - 4 } & perempuan & 86 & 46,44 \\
\hline
\end{tabular}

Tabel1 menunjukkan bahwa usia responden yang terbanyak dalam penelitian ini adalah $16-$ 18 tahun dan berjenis kelamin laki-laki. 
Tabel 2

Konsep Diri pada Remaja Yang Mengalami Bullying $(\mathrm{n}=183)$

\begin{tabular}{llcllll}
\hline \multicolumn{2}{c}{ Konsep Diri } & $\mathrm{f}$ & & $\%$ \\
\hline Positif & \multicolumn{2}{c}{88} & & 48,09 \\
\hline Negatif \\
\hline Tabel 2 menunjukkan bahwa proporsi & 95 & negatif & lebih & banyak & dibandingkan & yang \\
responden & yang mempunyai konsep diri & positif. & & & &
\end{tabular}

Tabel 3

Ketidakberdayaan remaja yang mengalami bullying $(\mathrm{n}=183)$

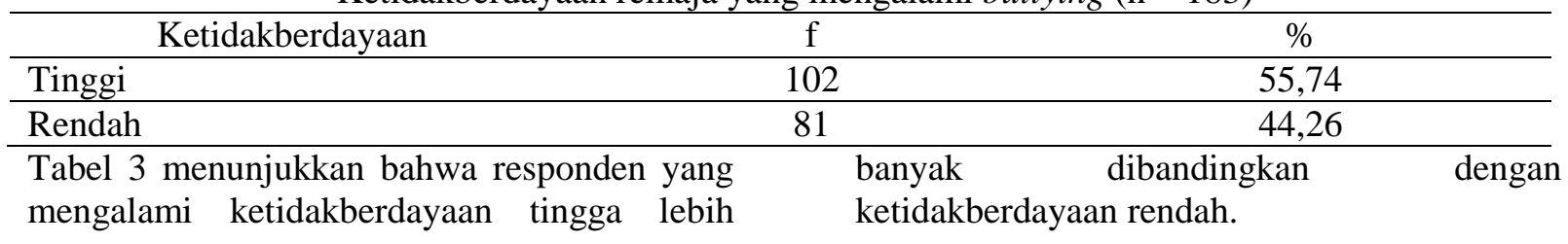

Tabel 4

Risiko bunuh diri remaja yang mengalami bullying $(\mathrm{n}=183)$

\begin{tabular}{|c|c|c|}
\hline Risiko Bunuh Diri & $\mathrm{f}$ & $\%$ \\
\hline Tinggi & 24 & 13,11 \\
\hline Rendah & 159 & 86,88 \\
\hline
\end{tabular}

Tabel 4 menunjukkan bahwa responden cenderung berisiko bunuh diri rendah lebih banyak dibandingkan yang berisiko tinggi.

Tabel 5

Hubungan konsep diri dengan ketidakberdayaan pada remaja yang mengalami bullying $(\mathrm{n}=183)$

\begin{tabular}{|c|c|c|c|c|c|c|c|c|c|}
\hline \multirow{3}{*}{ Variabel } & & \multicolumn{4}{|c|}{ Konsep Diri } & \multirow{2}{*}{\multicolumn{2}{|c|}{ Total }} & \multirow{3}{*}{$95 \% \mathrm{CI}$} & \multirow{3}{*}{$\begin{array}{c}p \\
\text { value }\end{array}$} \\
\hline & & \multicolumn{2}{|c|}{ Positif } & \multicolumn{2}{|c|}{ Negatif } & & & & \\
\hline & & $\mathrm{f}$ & $\%$ & $\mathrm{f}$ & $\%$ & $\mathrm{f}$ & $\%$ & & \\
\hline \multirow{2}{*}{ Ketidakberdayaan } & Tinggi & 32 & 17,49 & 53 & 28,96 & 85 & 46,45 & $-0,446--0,187$ & 0,000 \\
\hline & Rendah & 54 & 29,51 & 44 & 24,04 & 98 & 53,55 & & \\
\hline
\end{tabular}

Tabel 5 menunjukkan bahwa ada sebanyak 53 responden $(28,96 \%)$ yang memiliki konsep diri negatif kecenderungan mengalami ketidakberdayaan tinggi. Sedangkan diantara responden yang mempunyai konsep diri yang positif ada 32 responden $(17,49 \%)$ yang mengalami ketidakberdayaan tinggi.Hasil analisis menunjukkan bahwa ada hubungan antara konsep diri dengan ketidakberdayaan $(p<0,05)$.

Tabel 6

Hubungan konsep diri dengan risiko bunuh diri pada remaja yang menghalami bullying $(\mathrm{n}=183)$

\begin{tabular}{|c|c|c|c|c|c|c|c|c|c|}
\hline \multirow{3}{*}{ Variabel } & & \multicolumn{4}{|c|}{ Konsep Diri } & \multirow{2}{*}{\multicolumn{2}{|c|}{ Total }} & \multirow{3}{*}{$(95 \% \mathrm{CI})$} & \multirow{3}{*}{$\begin{array}{c}p \\
\text { value }\end{array}$} \\
\hline & & \multicolumn{2}{|c|}{ Positif } & \multicolumn{2}{|c|}{ Negatif } & & & & \\
\hline & & $\mathrm{f}$ & $\%$ & $f$ & $\%$ & $\mathrm{f}$ & $\%$ & & \\
\hline \multirow{2}{*}{ Risiko Bunuh Diri } & Tinggi & 70 & 38,79 & 90 & 49,18 & 160 & 87,97 & \multirow{2}{*}{$-0,337--0,040$} & \multirow{2}{*}{0,012} \\
\hline & Rendah & 16 & 0,87 & 7 & 0,38 & 23 & 1,25 & & \\
\hline
\end{tabular}

Tabel 6 menunjukkan bahwa ada sebanyak 90 responden $(49,18 \%)$ memiliki konsep diri negatif yang berisiko tinggi untuk melakukan bunuh diri. Sedangkan diantara responden yang mempunyai konsep diri yang positif juga mempunyai risiko bunuh diri tinggu yaitu sebesar 70 responden $(38,79 \% \%)$. Hasil analisis menunjukkan bahwa ada hubungan antara konsep diri dengan risiko bunuh diri ( $p$ $<0,012)$.

\section{PEMBAHASAN}

Hasil penelitian ini menunjukkan bahwa karakteristik remaja menunjukkan bahwa usia responden yang terbanyak dalam penelitian ini adalah $16-18$ tahun, yaitu sebesar 57,92\% (106 responden) dan responden yang berjenis kelamin laki-laki lebih banyak dibandingkan perempuan, yaitu sebesar 53,55\% (97 responden). Menunjukkan bahwa perilaku bullying sering kali dilakukan oleh remaja putra. 
Hasil penelitian ini menunjukkan bahwa responden yang memiliki konsep diri yang negatif maka kecenderungan mengalami ketidakberdayaan tinggi. Hasil analisis statistik menunjukkan adanya hubungan yang bermakna antara konsep diri dengan ketidakberdayaan $(\mathrm{p}=0.000, \alpha=0,05)$. Dengan demikian dapat disimpulkan pula bahwa konsep diri yang negatif berhubungan dengan ketidakberdayaan.

Menurut Rogers (dalam Tholib, 2010) dalam teorinya menyatakan bahwa konsep diri adalah konsep kepribadian yang paling utama, berisi ide-ide, persepsi dan nilai-nilai yang mencakup tentang kesadaran diri. Seseorang yang memiliki konsep diri yang negatif, maka seseorang tersebut tidak mampu mempersepsikan, bereaksi, memberikan arti dan penilaian serta membentuk abstraksi tentang dirinya, yang artinya sesorang tersebut tidak menunjukkan suatu kesadaran diri dan kemampuan untuk keluar dari diri untuk melihat dirinya sendiri. Sedangkan menurut Calhound \& Acocella bahwa sesorang yang memiliki konsep diri yang negatif adalah individu yang tidak bisa memahami dan mengerti tentang dirinya dan tidak dapat menerima segala macam fakta yang ada pada dirinya, baik kelebihan maupun kekurangan yang dimiliki.

Menurut William D. Brooks dan Philip Emmerat, ada empat tanda orang yang memiliki konsep diri negatif, yaitu: peka terhadap kritikan orang lain, tidak tahan terhadap kritik yang diterimanya, mudah marah, baginya koreksi sering kali dipersepsikan sebagai usaha menjatuhkan harga dirinya. Sangat responsif terhadap pujian, bersifat hiperkritis terhadap orang lain, selalu mengeluh, mencela dan meremehkan apapun atau siapapun, mereka tidak bisa mengungkapkan penghargaan atau kelebihan orang lain. Merasa tidak disenangi orang lain, merasa tidak diperhatikan, karena itu ia bereaksi kepada orang lain sebagai musuh, tidak pernah mempermasalahkan dirinya, tetapi akan menganggap dirinya sebagai korban dari sistem sosial yang tidak beres. Cenderung bersifat pesimis tehadap kompetensi, seperti terungkap dalam keenggananya untuk bersaing dengan orang lain dalam membuat prestasi. Seseorang cenderung menunjukkan ketidakberdayaanya terhadap tindakan yang dilakukan oleh orang lain maupun oleh dirinya sendiri.
Menurut Nanda dalam teorinya (Nanda, 2010) bahwa ketidakberdayaan merupakan persepsi atau tanggapan seseorang bahwa perilaku atau tindakan yang sudah dilakukannya tidak akan membawa hasil yang diharapkan atau tidak akan membawa perubahan hasil seperti yang diharapkan, sehingga seseorang sulit mengendalikan situasi yang terjadi atau mengendalikan situasi yang akan terjadi.

Hasil uji statistik juga menunjukkan bahwa adanya hubungan yang sangat erat antara konsep diri negatif dengan risiko bunuh diri, yaitu ( $p<0,012, \alpha=0,05)$.Dengan demikian dapat disimpulkan pula bahwa konsep diri negatif berhubungan dengan risiko bunuh diri. Hasil penelitian ini sejalan dengan teori yang dikemukakan oleh Rutter dan Behrendt bahwa ada empat faktor psikososial yang penting sebagai faktor risiko bunuh diri pada remaja yaitu ketidakberdayaan, permusuhan, konsep diri yang negatif.

Teori yang menyatakan bahwa masalah yang tidak terselesaikan akan menimbulkan stres. Sejumlah penelitian melaporkan bahwa ketidakberdayaan atau stres dan kehidupan yang penuh stres merupakan peristiwa yang sangat terkait dengan gejala depresi atau ketidakberdayaan, yang kemudian akan meningkatkan risiko bunuh diri (Zhang et al. 2011, You et al. 2014).

Hasil penelitian di atas sejalan dengan hasil penelitian Kwok dan Shek (2010) bahwa ideide bunuh diri pada remaja memiliki hubungan dengan ketidak berdayaan, dan kuatnya hubungan antara ide-ide bunuh diri dengan ketidakberdayaan. Penelitian lain dari Chung dan Joung (2012) di Amerika dan Korea, depresi atau ketidakberdayaan adalah faktor risiko yang signifikan untuk bunuh diri. Sejalan pula dengan hasil penelitian sertiasih, at al (2013) di Yogyakarta menyatakan bahwa depresi atau ketidakberdayaan merupakan faktor terjadinya bunuh diri pada remaja. Penelitian lain yang dilakukan oleh Reed, Nugent \& Cooper (2015) didapatkan hasil bahwa ada hubungan yang kuat antara perilaku intimidasi dan perilaku yang berhubungan dengan bunuh diri, tetapi hubungan ini sering dimediasi oleh faktor-faktor lain, termasuk depresi, perilaku kekerasan, dan penyalahgunaan zat (Reed, Nugent, \& Cooper, 2015). 
Teori yang menyatakan bahwa kondisi depresi yang dialami dapat menimbulkan ketidakberdayaan. Ketidakberdayaan akan menyebabkan sesorang itu merasakan masa depan yang belum jelas dan pasti, merasa sangat tidak mungkin untuk benar-benar merasakan kepuasan di masa depan, tidak bisa membedakan masa depan akan seperti apa, merasakan apa yang diharapkan tidak sesuai dengan yang diinginkan dan ragu dalam mencapai cita-cita.

\section{SIMPULAN}

Perilaku bullying sering terjadi pada remaja, baik dalam bentuk verbal maupun non verbal, sehingga akan berdampak terhadap pelaku maupun korban bullying, terutama dampak psikososial yaitu berupa ketidakberdayaan yang akan berlanjut pada terjadinya risiko bunuh diri. Hal ini dibuktikan dari hasil penelitian ini, yaitu terdapat hubungan antara konsep diri dengan ketidakberdayaan dan risiko bunuh diri pada remaja yang mengalami bullying.

\section{DAFTAR PUSTAKA}

Astusti, Retno. (2008). 3 Cara Efektif Mengatasi K.P.A (Kekerasan Pada Anak). Jakarta: PT Gramedia Widiasarana Indonesia

Wirawan Sarwono, Sarlito. (2010). Pengantar Psikologi Umum. Jakarta : PT Raja Grafindo Persada.

Arikunto, S. (2010). Prosedur penelitian: Suatu Pendekatan Praktik. (Edisi Revisi). Jakarta : Rineka Cipta.

Muhith, Abdul. (2015). Pendidikan Keperawatan Jiwa. Yogyakarta : CV ANDI OFFSET

Rosman, Arieff Salleh., wardah mokhtar. (2007). Membentuk Jati Diri Remaja. Kualalumpur: $\quad$ PTS Professional Publishing

Marchdante, J . Keren dkk. (2014). Imu Kesehtan Anak Esensial. Jakarta : PT Gramedia Sobur, Alex. (2011). Psikologi Umum. Bandung: Pustaka Setia.

Tim Yayasan Semai Jiwa Amini (sejiwa). (2008). Panduan Bagi Orang Tua dan
Guru Mengatasi Kekerasan di Sekolah dan Lingkungan. Jakarta : PT Gramedia

Arikunto, S. (2006). Prosedur Penelitian. Jakarta : Rineka Cipta.

Azwar, Saifuddin. (2010). Metode Penelitian. Yogyakarta: Pustaka Pelajar.

Carpenito, dkk. (2013). Buku Saku Diagnosa Keperawatan. Jakarta : Penerbit Buku Kedokteran EGC.

Dermawan Deden., Rusdi. (2013). Keperawatan Jiwa; Konsep Dan Kerangka Kerja Asuhan Keperawatan Jiwa. Yogyakarta : Gosyen Publishing.

Dourman, Karel. (2013). Waspadai stroke usia muda. Jakarta : Cerdas.

Dharma, Kelana Kusuma.(2011). Metodologi Penelitian Keperawatan. Jakarta :TIM.

Doenges, M., Townsend M. (2008). Nursing Diagnosis manual ed 2. Philadelphia : F.A. Davis company.

Erlinafsiah. (2010). Modal Perawat Dalam Praktik Keperawatan Jiwa. Jakarta : TIM.

Kanine, Esrom. (2011). Pengaruh terapi generalis dan logoterapi individu terhadap respon ketidakberdayaan klien diabetes melitus di rumah sakit provinsi sulawesi utara tesis universitas

Nicola Morgan. (2014). Panduan Mengatasi Stres bagi Remaja, Terj. dari The Teenage Guide of Stress oleh Dewi Wulansari. Jakarta: Penerbit Gemilang. Cet. I, h.137

Ponny Retno Astuti. (2008). Meredam Bullying: 3 Cara Efektif Mengatasi Kekerasan Pada Anak . Jakarta: UI Press.

Edupost (2015) Riset ICRW: 84 persen Anak Indonesia Alami Kekerasan di Sekolah, diakses pada tanggal 07 September 2015 dari http: edupost.id/beritapendidikan/riseticrw-84-persen-anakindonesia-alami-kekerasan-di-sekolah). 
Qommarria, Rostanti. (2015), KPAI: Kasus Bullying di Sekolah Meningkat Selama 2015, diakses pada tanggal 23 Juni 2016 dari

http://www.republika.co.id/berita/nasion al/ umum/15/12/30/o067zt280-kpaikasus-bullying-di-sekolahmeningkatselama-2015

Mangklara K, Skapinakis P, Gkatsa T, Bellos S, Araya R, Stylianidis S et al. (2012). Bullying behaviour in schools socioeconomic position and psychiatric morbidity: A cross-sectional study in late adolescents in Greece. Biomed Central 2012; 6:8. doc:10.1186/17532000-6-8

MKenna M.Hawk E, Mullen J, Hertz M. (2011). The association between bullying behavior and health risks among middle school and high school students in Massachusetts. Morbid Mortal Weekly Report 2011: 60: 465-71

Goldbaum, Craig Pepler. Connolly. (2003). Developmental trajectories of victimization: Identifying risk and protective factors. J Appl School Psychology; 2003: 19: 139-56

Altangerl,U, Liou, J. C, Pi-Ming Ye. (2014). Prevalence and Predictors of Suicidal Behavior Among Mongolian High School Students. Community Ment Health $J \quad .50: 362-372 \quad$ DOI $10.1007 / \mathrm{s} 10597-013-9657-8$

Bertera, M. E. (2007). The Role of Positive and Negative Social Exchanges Between Adolescents, their Peers and Family as Predictors of Suicide Ideation. Child Adolesc Soc Work J 24:523-538 DOI 10.1007/s10560-007-0104-y

Biddle, L., Gunnell, D., Sharp, D., \& Donovan, J. (2004). Factors influencing help seeking in mentally distressed young adults: A cross-sectional survey. British Journal of General Practice

Bridge, A.J, Goldstein, R.T, David, A.D. (2006). Adolescent suicide and suicidal behavior. Journal of Child Psychology and Psychiatry 47:3/4 doi:10.1111/j.1469-7610.2006.01615.x
Caskey. (2007). Adolescent Adjustment to the Middle School

Forintos,D. P, Sallai, J, Rózsa, S. (2010). Adaptation of the Beck Hopelessness Scale in Hungary. Psychological Topics. 
Jurnal Keperawatan Jiwa Volume 8 No 1 Hal 1 - 8, Februari 2020

FIKKes Universitas Muhammadiyah Semarang bekerjasama dengan PPNI Jawa Tengah 